Haris Hassan ${ }^{1}$

\title{
Social Implications of Corruption in Developing Countries: Case Study of Pakistan and India
}

\begin{abstract}
Background: The existence of corruption threatens all aspect of a society, be that social, economic or political. Corruption is more pronounced in developing countries; however, it attracts very little attention from decision-makers. This paper analyses the social implications (health and education) of corruption in India and Pakistan. According to the Corruption Perception Index Report (2019), these countries are perceived to be the most corrupt ones.
\end{abstract}

Objectives: Corruption has been researched enormously with respect to its economic and political consequences, but not much attention has been given to its social implications on human rights. Corruption violates human rights directly or indirectly. Therefore, this paper aims to elaborate the links (direct and indirect) between corruption and human rights and focus on the consequences of corruption on health and education; it also aims to present anti-corruption policies to curb corruption in the investigated countries.

Methods: The research employs a systematic literature review method (PRISMA-P 2015) that identifies currently available research, selects and assesses contribution, analyses and synthesises data, and presents pieces of evidence with a justified conclusion. It also encourages researchers to apply PRISMA protocols in future researches.

Results: The results show that more than $80 \%$ of the reviewed articles argue that corruption is one of the invincible reasons for the people's dire social condition in India and Pakistan; moreover, corruption remains ignored, which shows that there are gaps to understand how corruption can extremely dent the right to education and health.

KEYWORDS: Corruption, social implications in developing countries, human development, human rights, impacts of corruption on health and education.

RECEIVED 28 July 2021; ACCEPTED 10 December 2021.

\section{INTRODUCTION}

Corruption is a multifaceted phenomenon that exists in every society in different forms. Complete elimination and detection of corruption is hard and expensive because of its blatant existence. However, the historical and cultural background of countries does contribute to the intensity of corruption. Klitgard (1988) argues that corruption is prevalent in a monopolistic system where one party has control over certain goods and services and holds power to decide to whom and how much of these goods and services are to be given. In such cases, inequality prevails. Arora (2009) finds out that the poor class of society suffers from inequality where the poor further weaken and are unable to hold the rich accountable for corruption. Since corruption is deeply rooted in developing countries, very little attention has been given to it by politicians. Also, the issue of corruption has not been considered as serious as it should be. No demanding course of action has been mobilised against corruption.

In our paper, we find answers for the following research questions:

What are the human rights implications of corruption in developing economies?

What are the policy alternatives to curb corruption in developing countries?

What are the missing points of current research in the field of corruption in developing states?

1 Faculty of Social Sciences, Charles University, Prague 
The countries chosen for this paper are Pakistan and India because according to the Corruption Perception Index Report (2019), these countries are perceived to be the most corrupt ones. None of them secures a rank in the (at least) top 50 least corrupt countries. The reason why we chose these countries is that they have the same colonial legacy. They are path dependent; the phenomenon of 'path dependence' is defined as: 'history does matter or past influences future' or 'path dependence is characterized by historical sequences where contingent events set institutional patterns or series of events holding deterministic properties' (Mahoney 2000). Moreover, Sewell (1996) defines path dependency as whatever had occurred in the past carries effects on the future happening. Nevertheless, since then, the colonial impact has been prevalent in the institutional and political structures. Today, the above-mentioned economies are undergoing social, economic and political chaos; the reasons could be many, but the endemic level of corruption is the primary one and is enormously path dependent (Angeles and Neanidis 2015).

The research employs a systematic literature review (SLR) method. A systematic review is a particular methodology which identifies currently available research, selects and assesses contributions, analyses and synthesises data and presents pieces of evidence with a justified conclusion.

First, through a systematic review of literature, we define the term corruption and seek its consequences in developing countries. Moreover, we focus on and evaluate the social (health and education) implications of corruption in developing countries. The criterion to choose countries for this research is based on 'similar historical legacy' of both countries. Secondly, we link the divergence of public investment in the social sector and low human development with corruption. Lastly, we analyse policy recommendations for curbing corruption in developing countries.

\section{RESEARCH PROBLEMS AND OBJECTIVES}

Corruption carries adverse effects on all aspects of a society, be that social, political, economic or cultural. For instance, Leff (1964), Huntington (1968), Acemoglu and Verdier (1998) and Gründler and Potrafke (2019) researched the economic implications of corruption. Moreover, Adsera et al (2003), Le (2003), Park (2003) and Pellegerini and Gerlagh (2008) explain the relation between corruption and political instability. Drapalova et al (2019) describe the negative effects of corruption on democracy. However, less attention has been given to social implications of corruption with respect to human rights in particular, though corruption violates human rights directly or indirectly. Therefore, the main objectives of this research are to explain the relation between corruption and social human rights (health and education) through an SLR, and to explain how corruption diverts public spending from social capital projects specifically and to identify the theories that seed corruption, in general, and finally to suggest policy recommendations to combat corruption.

\section{LINKS BETWEEN CORRUPTION AND HUMAN RIGHTS}

This paper discusses both direct and indirect links between corruption and human rights violations. For instance, Gupta, Davoodi and Tiongson (2000) discuss the direct links between corruption and human rights. They argue that corruption can violate basic human rights (education and health) particularly in two different ways: either the cost of services can be increased, so that the disadvantaged individuals cannot afford them, or the quality of services can be reduced by corruption. Similarly, Ackay (2006) and Terme and Mauro (1998) explain the indirect links between corruption and human rights. They argue that corruption diverts public spending from human developmental projects to capital-intensive projects (discussed below) which leads to low level of health and education facilities. Such an underinvestment in the social sector ends in violation of basic human rights. Therefore, an ordinary person of a state does not demand a lavish life, but instead demands for basic needs of life from the people in power (Fuhr 2013).

The Universal Declaration of Human Rights (1948) comprehensively defines human rights. In this paper, we include articles of Universal Declaration of Human Rights (UDHR) that define human rights in regard to social protection (health and education). All human beings are born free and equal in dignity and rights. They are bestowed with morality and should act towards one another in a spirit of brotherhood (Article 1). Moreover, all human beings are entitled to have equal access to public service in their country. Everyone, as a member of society, has the right to social security including health and education for the well-being and development of her/his personality (Articles 21, 22, 25, 26). In this paper, we investigate the implications of corruption on human development, 
that is, health and education in particular. As Sen (2005) argues, the concept of human rights and human capabilities go well with each other. Sen (1998) goes on defining development as 'freedom- the process of expanding real freedom that people can enjoy in a society'. Health and education are believed to be important factors that freedom rely on. Miletzki and Broten (2017) argue that the availability of health and education facilities is among the most important factors that human development is based on.

\section{THEORETICAL FRAMEWORK}

The problem of corruption has been dealt with by a number of authors (see, e.g. Ackerman and Søreide 2011; Caiden and Caiden 1977). The simplest definition of corruption is as follows: corruption is characterised by the abuse of a public position for selfenrichment (Nye 1989). Jansinc (2019) defines corruption in the following way: 'Corruption is a complex social activity in which money, goods, or other resources that belong to a public organization are exchanged or transferred covertly in a way that benefits particularistic actors instead of the organization or the general public'.

Based on the synthesis of available literature, the definition and categorisation of corruption are presented in Table 1.

Tab. 1:

\begin{tabular}{|c|c|c|}
\hline \multirow[t]{4}{*}{$\begin{array}{l}\text { Theories of } \\
\text { corruption }\end{array}$} & Public choice & $\begin{array}{l}\text { Studies only the decisions taken by individuals, public officials try to maximise } \\
\text { their benefit, a decision to take a bribe is a result of rational calculation }\end{array}$ \\
\hline & $\begin{array}{l}\text { Organisational culture } \\
\text { theories }\end{array}$ & $\begin{array}{l}\text { The cause of corruption lies in group behaviours taking place inside an organisation's } \\
\text { structure and culture. The corrupt culture of an organisation determines an } \\
\text { individual's corrupt behaviour }\end{array}$ \\
\hline & $\begin{array}{l}\text { Public administration } \\
\text { theories }\end{array}$ & $\begin{array}{l}\text { Reforms within the sense of the New Public Management undermine traditional } \\
\text { functions of the public sector and ultimately have a negative impact on accountability }\end{array}$ \\
\hline & Collective action problem & $\begin{array}{l}\text { Corruption arises because agents think that the other agents are also corrupted. } \\
\text { Thus, corruption becomes an expected behaviour in a society. Corruption, therefore, } \\
\text { becomes a feeding and the most rational strategy }\end{array}$ \\
\hline
\end{tabular}

However, definition and indicators of measuring corruption depend on the dimension that is being analysed since it is a multidimensional phenomenon. This is the reason why finding one universal definition of corruption is difficult. Yet, there is a broad consensus among the scholars on the definition of corruption; they define corruption as the 'misuse of public office for personal or private interest' (Plaček 2018). This definition is supported by principal-agent theory, where the agent is probably a public official holding discretionary power while principal refers to an individual who seeks public goods and services. The arrangements between an agent and a principal are strategic and inevitable, given the situation where the agent misuses the given authority for personal interest while the principal is in need. Yet, the principal is hesitant to report the abuse because of the high monitoring cost (Groenendijk 1997). The International Country Risk Guidance data underpins that the principal-agent definition of corruption fits in potential corrupt cases, for instance, nepotism, bribery, extortion of money and close personal relations among politicians and business tycoons (Arestis and Caner 2010).

Moreover, corruption has been mainly classified into two main kinds. The first category is grand corruption where top-level bureaucrats or politicians are involved. Grand corruption refers to a situation where politicians are involved in a public-private partnership involves a considerable amount of payments and outcomes that affect all (Mashali 2012). The second main category of corruption is petty corruption, where street-level bureaucrats are involved with citizens in taking bribes for providing different public goods and services (Ariane et al 2007). Petty corruption indicates the magnitude of payment given or received, but not the overall impact of it on the government policy (Scott 1972). There are multiple kinds of such corruption; it can be in any form, starting from utility bills to public sector contracts (Kochanek 1993). Petty corruption is a gateway to grand corruption because it creates opportunities for grand corruption (Mashali 2012). 


\section{METHODOLOGY AND RESEARCH METHODS}

The research focuses on the social implications of corruption in emerging economies. For this research, two countries, that is, Pakistan and India, have been selected. According to the Transparency International report (2019), these economies are in the cluster of the most corrupt countries in the world. Systematic reviews are based on a continuum from knowledge-building and theory-generating to aggregating and summarising (Finfgeld-Connett and Johnson 2013). SLR has obtained importance in multiple fields, including public policy. To include unbiased search techniques for the identification of relevant articles and ensure objectivity and transparency, this systematic review was conducted in accordance with PRISMA protocols (Liberati et al 2009; Petticrew and Robbert 2008). The identification of analytical studies related to corruption in developing countries is premised on the following.

Gathering of relevant studies: This research follows PRISMA-P (2015) to identify relevant studies from journals, book chapters and well-renowned authors from different fields of studies, for instance, corruption, human rights, human development, political science, economics, sociology and political economy. Subsequently, an inventory of the articles was formed. This inventory aimed to have a collection of the most recent studies related to the topic; also, such a collection helps to increase the count of keywords. An Excel sheet was created to manage data and records for reviews. Moreover, relevant literature was studied from bibliographies of reviewed articles. The reviewed literature aimed to identify the social implications of corruption in transition economies.

The search strategy was premised on keywords; approximately 20 keywords and synonyms were taken into consideration to identify relevant articles. A dataset was formed for the assessment of articles' quality in the field of corruption and social human rights (Pahlevan Sharif et al 2019). Additionally, countries' names, which are being researched in this article, were also part of the search strategy. Google Scholar and Web of Sciences were the main search sources for using relevant concepts to locate applicable studies; majority of the studies were from peer-reviewed journals, for instance, JSTOR and Elsevier. Moreover, reports from databases, such as World Governance Indicators, World Bank, World Health Organisation and World Economic Forum, were also utilised to critically analyse health and education indicators in these developing countries (see Table 2).

Tab. 2:

\begin{tabular}{|c|c|c|}
\hline Sources & Keywords & Interpretation \\
\hline Web of Science & $\begin{array}{l}\text { 'Corruption in developing countries' AND 'the effects of corruption in } \\
\text { developing countries' AND 'implications of corruption in developing } \\
\text { countries' AND 'human rights implications of corruption' AND 'corruption } \\
\text { effects on human right' AND 'human development' ('social implications*' } \\
\text { OR 'effects*' OR 'impacts' OR 'influence*' 'poverty and corruption' } \\
\text { OR 'nexus' OR 'health indicators' OR 'social indicators' OR 'bribery' OR } \\
\text { 'nepotism' OR 'embezzlement' OR 'political corruption*' OR 'bureaucratic } \\
\text { corruption' OR 'corrupt practices*') }\end{array}$ & $\begin{array}{l}\text { The existence of keywords was } \\
\text { confirmed in the resulting articles }\end{array}$ \\
\hline Google Scholar & $\begin{array}{l}\text { 'Corruption in developing countries' AND 'the effects of corruption in } \\
\text { developing countries' AND 'implications of corruption in developing } \\
\text { countries' 'human rights implications of corruption' AND 'corruption } \\
\text { effects on human right' AND 'human development' ('social implications*' } \\
\text { OR 'effects*' OR 'impacts' OR 'influence**' poverty and corruption' OR } \\
\text { 'nexus' OR 'health indicators' OR 'education indicators' OR 'bribery' OR } \\
\text { 'nepotism' OR 'embezzlement' OR 'political corruption*' OR 'bureaucratic } \\
\text { corruption' OR 'corrupt practices*') }\end{array}$ & $\begin{array}{l}\text { The existence of keywords was } \\
\text { confirmed in the resulting articles }\end{array}$ \\
\hline
\end{tabular}

Screening phase: As mentioned above, an inventory of articles, based on the techniques of Ugur and Dusgupta (2011), was created. The main objective of this inventory was to store all the downloaded articles, which helped in the screening phase. Titles and abstracts were screened by independent reviewers; however, papers relevant to the risk of bias were excluded. Moreover, to extract the data, a pilot test of 30 randomly selected papers was done for obtaining and confirming the data in accordance with PRISMA-P (2015). Approximately 208 articles were downloaded; the turnout of relevant articles was 160 during the first phase of screening. Studies relevant to the topic and its objectives were included according to the selection criteria. However, during the second screening, 
the studies that were not relevant had been excluded. A total of 105 closely related articles (mostly academic articles in English) were considered and reviewed to achieve the objectives of this paper. After a review of relevant studies, it was possible to mention characteristics of the articles, such as the aim of the research, used data, methodologies, limitations and results.

\section{RESULTS}

RQnr 1: What are the human rights implications of corruption in India and Pakistan? Tables 3 and 4 showing systematic analysis of corruption with its dire consequences on health and education answer the above question for two different countries. However, more than $80 \%$ of the reviewed articles argue that corruption is one of the invincible reasons of people's dire social condition in India and Pakistan. The following results also identify the main factors contributing to the creation of a corrupt environment. Such factors include weak institutional structure, political instability, lack of morality, lack of political-will and colonial legacy.

Moreover, a broad consensus exists among the scholars on the fact that corruption diverts public investment from the social sector to capital-intensive projects. Policymakers tend to invest in projects that give monetary benefits in the form of bribes and kickbacks. Such divergence of public investment ends up in low human development, which in turn affects the social human rights of citizens. For results, see Tables 3 and 4.

Tab. 3:

\begin{tabular}{|c|c|}
\hline \multicolumn{2}{|l|}{ Corruption in Pakistan } \\
\hline CPI Report (2019) & $\begin{array}{l}\text { Pakistan ranks } 120 \text { out of } 180 \text { countries on the Corruption Perception Index, scoring } 32 \text { points out of } 100 \\
\text { points }\end{array}$ \\
\hline $\begin{array}{l}\text { World Economic Forum, } \\
\text { GCR (2019) }\end{array}$ & $\begin{array}{l}\text { Overall institutional performance of Pakistan has a score of } 47 \cdot 7 / 100 \text { points and the country ranks } 107 \text { out } \\
\text { of a total of } 141 \text { countries. The level of organised crimes has a score of } 47.4 / 100 \text { points, placing the country } \\
\text { at } 112 \text { rank out of } 141 \text { countries. The level of transparency score is } 33 / 100 \text { points, which places the country } \\
\text { at } 101 \text { position among } 141 \text { countries }\end{array}$ \\
\hline Ali (2020) & $\begin{array}{l}\text { Politicisation of state institutions is the biggest problem in Pakistan. NAB fails to investigate high-profile } \\
\text { corruption cases due to political influence. Panama case has not been deeply investigated }\end{array}$ \\
\hline Verkaaik (2001) & $\begin{array}{l}\text { During the last three decades, Pakistan's prime ministers have been disqualified on corruption charges. } \\
\text { In the } 1990 \text {, the accountability commission was introduced, which functioned as a financial check and } \\
\text { balance instrument, yet failed to perform its function }\end{array}$ \\
\hline Bashir et al (2011) & $\begin{array}{l}\text { It is perceived that getting work done without having a public officer bribed is not possible. Research } \\
\text { shows that } 82 \% \text { of the government employees either saw or experienced misconduct in the last } 1 \text { year and } \\
90 \% \text { people do not report corrupt activities }\end{array}$ \\
\hline Anwar and Bilquees (2003) & $\begin{array}{l}\text { Bad governance affects the poor class of the society by various means, including income inequality and } \\
\text { reduced public spending on human development }\end{array}$ \\
\hline Miankhail (2009) & $\begin{array}{l}\text { Due to the lack of accountability and transparency in the public sector of Pakistan, misallocation of } \\
\text { resources is the key problem. Public funds have been distorted, protecting the interest of elites }\end{array}$ \\
\hline Khan (2016) & $\begin{array}{l}\text { Having colonial roots and due to political instability (due to civil-military clashes) and high political } \\
\text { interference, state institutions have become shallow and no concrete course of action is taken to combat } \\
\text { corruption }\end{array}$ \\
\hline Chene (2008) & $\begin{array}{l}\text { In Pakistan, corruption exists in different forms, namely, bribery, nepotism, extortion, political and } \\
\text { bureaucratic corruption or abuse of power by influential public officials }\end{array}$ \\
\hline $\begin{array}{l}\text { CPI Report (2018), Vittal and } \\
\text { Mahalingam (2004) }\end{array}$ & $\begin{array}{l}\text { The gravity of corrupt activities is dependent on the level of morality in society. Corrupt practices are an } \\
\text { integral part of routine activities in Pakistan. The level of corruption in Pakistan has surged }\end{array}$ \\
\hline Javaid (2010) & $\begin{array}{l}\text { Grand corruption is widespread in developmental projects, particularly in public sector procurement. } \\
\text { Some estimates show that corruption causes some Rs. } 200 \text { billion loss to the economy every year }\end{array}$ \\
\hline Farooq et al (2013) & $\begin{array}{l}\text { Corruption impedes economic growth and weakens the institutions. Similarly, Pakistan's economy has } \\
\text { seen a sluggish growth due to a rampant increase in the level of corruption }\end{array}$ \\
\hline
\end{tabular}


Continued Tab. 3:

\begin{tabular}{|c|c|}
\hline \multicolumn{2}{|l|}{ Corruption in Pakistan } \\
\hline Paredes-Solis et al (2011) & $\begin{array}{l}\text { People in Pakistan believe that they are forced to pay bribes to obtain public medical services. In the year } \\
2002,29 \% \text { of people and in the year } 2004,24 \% \text { of people were using the country's public health services. } \\
\text { Due to inadequate health facilities, people tend to use (who can afford) available private health services }\end{array}$ \\
\hline Coleman (2004) & $\begin{array}{l}\text { Weak governance, corruption and political instability in Pakistan led to unstable economic and social } \\
\text { development. Governments have repeatedly failed to lift millions of people from drowning in poverty }\end{array}$ \\
\hline Ahmad et al (2013) & $\begin{array}{l}\text { The primary education system has been neglected in Pakistan. Political interference ends up in corruption, } \\
\text { which in turn reduces the financial resources for the education sector, due to which school staff are not } \\
\text { well paid and are untrained }\end{array}$ \\
\hline $\begin{array}{l}\text { World Bank Report (2015), } \\
\text { Choudhry (2014) }\end{array}$ & $\begin{array}{l}25 \% \text { of the population in Pakistan live below the poverty line. Pakistan's multidimensional poverty } \\
\text { headcount ratio is } 49.4 \% \text {, while the country has been ranked } 145 \text { on the Human Development Index }\end{array}$ \\
\hline Khan (2007), WHO (2014) & $\begin{array}{l}\text { Pakistan has always been criticised for its public spending priorities. The country spends } 2.6 \% \text { of its total } \\
\text { GDP on health care and } 2.4 \% \text { on education }\end{array}$ \\
\hline $\begin{array}{l}\text { UNIGME, WHO (2018), } \\
\text { UNFPA (2019) }\end{array}$ & $\begin{array}{l}\text { Child mortality rate is } 69.31 / 1000 \text { live births under } 5 \text { years and } 46,482.00 \text { between } 5 \text { and } 14 \text { years of age. } \\
\text { Also, more than } 30 \% \text { of children are victims of stunted growth due to malnutrition. Pakistan has the } \\
\text { highest maternal mortality rate in South Asia due to unavailability of health facilities }\end{array}$ \\
\hline \multicolumn{2}{|l|}{ Corruption in India } \\
\hline $\begin{array}{l}\text { Transparency International } \\
(2019)\end{array}$ & $\begin{array}{l}\text { According to Transparency International (2019) Report, India ranks } 80 \text { out of } 180 \text { countries on the } \\
\text { Corruption Perception Index, obtaining } 40 \text { points out of } 100\end{array}$ \\
\hline $\begin{array}{l}\text { World Economic Forum, } \\
\text { GCR (2019) }\end{array}$ & $\begin{array}{l}\text { Overall institutional performance of India shows a score of } 56.8 / 100 \text { points and India ranks } 59 \text { out of a total } \\
\text { of } 141 \text { countries. The level of organised crimes has a score of 55.0/100 points, placing India at } 91 \text { position } \\
\text { out of } 141 \text { countries. The level of transparency score is } 41.0 / 100 \text { points, which places the country at } 66 \\
\text { position among } 141 \text { countries }\end{array}$ \\
\hline $\begin{array}{l}\text { Transparency International } \\
\text { India Report (2005) }\end{array}$ & $\begin{array}{l}\text { In } 2005,11 \text { public sector departments had been surveyed; } 62 \% \text { of respondents (citizens) said corruption } \\
\text { is a serious issue. They shared a personal experience of paying bribes. The study reveals that the common } \\
\text { people pay Rs. } 210,680 \text { million as bribe per year }\end{array}$ \\
\hline $\begin{array}{l}\text { HDI Report (2019) and } \\
\text { Global Monitoring Report } \\
(2014)\end{array}$ & $\begin{array}{l}\text { India ranks } 129 \text { with an HDI value of } 0.647 ; 30 \% \text { of the world's extremely poor people live in India. } \\
\text { Corruption is perceived to be one of the main barriers to human development in India }\end{array}$ \\
\hline $\begin{array}{l}\text { World Bank (2018) and } \\
\text { UNICEF/WHO (2009) }\end{array}$ & $\begin{array}{l}37 / 1000 \text { children die before their fifth birthday; } 26 \% \text { of India's population does not have access to } \\
\text { sanitation, which causes diarrhoea in children that becomes a reason of approximately } 386,600 \text { child } \\
\text { deaths each year }\end{array}$ \\
\hline $\begin{array}{l}\text { Global Monitoring Report } \\
\text { (2014) }\end{array}$ & $\begin{array}{l}\text { Corruption is prevalent in the Indian education system; } 71 \% \text { of the population is dependent on the public } \\
\text { education system. The amount of money that goes in petty corruption is nearly INR. } 41,370 \text { million per } \\
\text { annum }\end{array}$ \\
\hline Quah (2008) & $\begin{array}{l}\text { Corruption in India, either grand or petty, is routinely being practiced. In } 2008 \text {, the World Bank } \\
\text { investigated corruption scandals in India's healthcare projects of } \$ 568 \text { million. Indian high-ranking public } \\
\text { officials defalcate billions of rupees, while street-level bureaucrats are busy stealing millions }\end{array}$ \\
\hline Chauchard et al (2019) & $\begin{array}{l}\text { Data from India shows that politicians rapidly add up to their financial assets after assuming public } \\
\text { offices. A public survey was conducted in } 2015 \text {, which found that respondents linked politicians' wealth } \\
\text { accumulation to corruption }\end{array}$ \\
\hline Rose and Peiffer (2018, p. 13) & $\begin{array}{l}\text { Governmental regulations favour public servants to receive unofficial payments from entrepreneurs who } \\
\text { are in need of urgent legal documentation or need it by overlooking legal requirements. Such people } \\
\text { influence laws and regulations for self-interest }\end{array}$ \\
\hline $\begin{array}{l}\text { Cheng and Urpelainen } \\
(2019)\end{array}$ & $\begin{array}{l}\text { In India, a corrupt politician tends to finance a road or highway project rather than a school project due to } \\
\text { substantial personal monetary benefits in the form of kickbacks }\end{array}$ \\
\hline
\end{tabular}

NAB, National Accountability Bureau 
Tab. 4:

\begin{tabular}{|c|c|}
\hline \multicolumn{2}{|c|}{ Corruption and public spending } \\
\hline $\begin{array}{l}\text { Tanzi (1998) and Mauro } \\
\text { (1996) }\end{array}$ & $\begin{array}{l}\text { Corruption considerably reduces public spending, and the argument is contentious; one school of thought } \\
\text { argues that corruption increases public spending as a percentage of GDP, while another school of thought } \\
\text { believes that corruption has no effects on public spending }\end{array}$ \\
\hline Shleifer and Vishny (1993) & $\begin{array}{l}\text { Public spending in corruption-prevalent countries is believed to be less effective; the involved corrupt } \\
\text { agents nominate projects which give them more financial benefits in the form of bribes and kickbacks }\end{array}$ \\
\hline Tanzi and Davoodi (1997) & $\begin{array}{l}\text { Public investment on human capital is distorted as a result of corruption, specifically education. Corrupt } \\
\text { public officials tend to invest in new construction projects rather than on human development }\end{array}$ \\
\hline Delavallade (2006) & $\begin{array}{l}\text { Public spending is the main tool for human development; curbing corruption must be the main goal of } \\
\text { emerging economies to ensure securing an applaudable place in Human Development Index ranking }\end{array}$ \\
\hline Sen (1999, p. 275) & $\begin{array}{l}\text { Corruption is one of the key constraints which makes government policies ineffective and pushes all } \\
\text { investments away from lucrative projects; also, it promotes and safeguards the mafia }\end{array}$ \\
\hline Chen and Neshkova & $\begin{array}{l}\text { Fiscal transparency increases budgetary matters and public sector performance and ensures } \\
\text { accountability to curb corruption. More fiscally transparent economies are perceived to be less corrupt }\end{array}$ \\
\hline $\begin{array}{l}\text { Sviderskyi and Lubentsov } \\
(2020)\end{array}$ & $\begin{array}{l}\text { Effects of bad governance exist in every dimension of life, which hampers the development of the modern } \\
\text { world. Moreover, it does negatively affect public funds and the public's trust in government officials to } \\
\text { control corruption }\end{array}$ \\
\hline $\begin{array}{l}\text { Machoski and De Araujo } \\
(2020)\end{array}$ & $\begin{array}{l}\text { The funds allocated for public health are diverted by public officials, which ultimately leaves effects on } \\
\text { public health services and causes reduced economic growth }\end{array}$ \\
\hline \multicolumn{2}{|c|}{ Impacts of corruption on human development } \\
\hline Akacay and Gebeye (2006) & $\begin{array}{l}\text { The framework of human development includes the broadening of choices, which is acquired by } \\
\text { enhancing human ability through social capital (education, health, nutrition) }\end{array}$ \\
\hline Saeed & $\begin{array}{l}\text { Governance is often correlated with human development (health and education) and per capita income. } \\
\text { Countries that are well developed are perceived to be less corrupt due to high per capita income and } \\
\text { better ranking in the Human Development Index }\end{array}$ \\
\hline $\begin{array}{l}\text { Gupta, Davoodi and } \\
\text { Tiongson (2000), } \\
\text { Kaufamann, Kraay and } \\
\text { Zoido-Lobaton (1999) }\end{array}$ & $\begin{array}{l}\text { Corruption either makes public services unaffordable or decreases their quality. Nevertheless, empirical } \\
\text { studies show that corruption decreases life expectancy and education level and also increases the death } \\
\text { rate of children }\end{array}$ \\
\hline $\begin{array}{l}\text { Akhter (2004) and Tran } \\
(2008)\end{array}$ & $\begin{array}{l}\text { Politicians and bureaucrats involved in corruption instigate poverty; corruption affects human } \\
\text { development. The mechanism of } \mathrm{CC} \text { depends on } \mathrm{HC} \text {, higher literacy ratio and life expectancy }\end{array}$ \\
\hline Hu and Mendoza (2013) & $\begin{array}{l}\text { Good governance, reduced level of corruption and well-functioning bureaucracy bring a breakthrough in } \\
\text { controlling mortality rate }\end{array}$ \\
\hline $\begin{array}{l}\text { Justesen and Bjornskov } \\
\text { (2014) }\end{array}$ & $\begin{array}{l}\text { The study finds out that poor people are comparatively much more vulnerable to corrupt practices of } \\
\text { public officials since these people highly depend on public goods and services due to an increased level of } \\
\text { poverty }\end{array}$ \\
\hline Buscaglia (2003) & $\begin{array}{l}\text { Corruption paves the path for organised crimes in every society; there exists a robust relationship } \\
\text { between organised crimes and corruption }\end{array}$ \\
\hline
\end{tabular}

CC, corruption control; HC, human capabilities

RQnr 2: What are the policy alternatives to curb corruption in developing countries?

Considering the filthy consequences of corruption, policies to curb corruption have long drawn attention. However, prevalence of the problem in developing countries and the lack of implementation of anti-corruption laws make it challenging to overcome the issue of corruption. Countries' institutional response is to mitigate corruption by establishing anti-corruption agencies; yet, the problem persists as a result of politicisation of institutions. In this article, we recommend and discuss the analyses of some anticorruption policies; these policies include political accountability, technological advancement along with decentralised information systems, introduction of social audits and institutional reforms, which need to be implemented to curb corruption in developing countries. 
As we discussed above, corruption lowers human development due to less investment in the social sector. However, Doig and Theobald (2000) believe that corruption ends up in taxing the poor, while Bardhan (1997), Lambsdorf (2007) and Murphy et al (1993) believe that it diverts investment from the social sector (health and education) which makes it easy for the corrupt individuals to digest public money. Table 5 contains anti-corruption policy analysis.

Tab. 5:

\begin{tabular}{|c|c|c|}
\hline \multicolumn{2}{|c|}{ Anti-corruption policy analysis } & \multirow{2}{*}{$\begin{array}{l}\text { References } \\
\text { Caillier (2010), Adsera et al } \\
\text { (2003) and } \\
\text { Rose-Ackerman (1999) }\end{array}$} \\
\hline $\begin{array}{l}\text { Political } \\
\text { accountability }\end{array}$ & $\begin{array}{l}\text { Political accountability is a baseline factor in rooting out corrupt practices; in a well- } \\
\text { democratic system, voters are capable of holding politicians accountable for their } \\
\text { corrupt behaviour }\end{array}$ & \\
\hline $\begin{array}{l}\text { Institutional } \\
\text { reforms }\end{array}$ & $\begin{array}{l}\text { Countries where corruption is widespread need institutional reform, which means } \\
\text { that on a daily basis, operational problems must be improved through control } \\
\text { systems, transparency in the system, robust accountability, improved recruitment, } \\
\text { training of official staff and a client-friendly appeal system }\end{array}$ & Johnson (1998) \\
\hline $\begin{array}{l}\text { Technological } \\
\text { advancement }\end{array}$ & $\begin{array}{l}\text { Technological advancement seems to have played a meaningful role in improving } \\
\text { transparency and reducing the level of corruption. Providing mobile texting service } \\
\text { to the public in order to report corruption cases can have a positive effect on curbing } \\
\text { corruption in Africa. However, it needs to have a decentralised information system } \\
\text { that can demolish the opportunities to indulge in corruption }\end{array}$ & Ionescu (2013) \\
\hline Social audits & $\begin{array}{l}\text { Social audits should be introduced in developing countries to maintain checks at } \\
\text { the organisational level. Social audits mean to identify and report organisational } \\
\text { problems as well as to enhance organisational performance. Social audits are } \\
\text { important in the health sector; in particular, it ensures greater accountability and } \\
\text { improves healthcare services }\end{array}$ & $\begin{array}{l}\text { Dhaktode (2016) and } \\
\text { Cockcroft et al (2008) }\end{array}$ \\
\hline
\end{tabular}

RQnr 3: What are the missing points of current research in the field of corruption in developing states? Investigating corruption is often based on quantitative researches, for instance, examining the effects of corruption on economic growth, citizens' voting behaviour, etc. needs quantitative data. Therefore, research in the field of corruption is dependent on quantitative data. Similarly, this article reviews scientific studies on corruption in the health and education sector that are based on quantitative data. However, qualitative studies do not contribute much in this paper.

Due to the multifaceted nature of corruption, it exists in every society and every sector of an economy and affects all the dimensions of a society. Therefore, corruption has been investigated and researched from different perspectives. For instance, Mauro (1995), Mo (2001) and Jain (2001) reviewed corruption, growth and development. Peters and Welch (1980), McCann and Dominguez (1998) and Klašnja et al (2016) investigated corruption from the perspective of citizens' voting behaviour. Moreover, Rotberg (2009) and Thachuk (2005) investigated corruption with respect to its global security and world order.

Corruption does not only instigate the issues discussed above, but also hits all aspects of a society. Where corruption has broadly been investigated from an economic and political perspective, little attention has been given to social issues occurring due to corruption in developing societies. In our research, we do not cover the entire social sector of developing countries; rather, we focus on health and education. Furthermore, the theoretical part of this paper classifies and discusses corruption in developing economies in general. However, the results are applicable for the investigated countries (Pakistan and India) only and not for all developing countries.

\section{DISCUSSION}

This paper shows that SLR has potential significance to identify and analyse social human rights issues related to corruption. Although systematic review methods have been used to analyse social, economic and political dimensions of corruption, for instance, impact of corruption on the health sector in Africa (Onwujekwe et al 2019), corruption in oil sector (Moisé 2020), effect of corruption 
on the quality of public delivery service (Molina 2017) and economic impact of corruption in low-income countries (Ugur and Dasgupta 2011). This paper, however, bridges the link between corruption and social human rights through an SLR. Moreover, this paper shows the intensity and threats posed by corruption to health and education sector in developing countries. Results identify factors such as lack of accountability and transparency, misallocation of public funds and protecting the interest of elites; however, such factors contributing to the rise of corruption in developing countries are specific to weak institutional structure. It is, therefore, important to educate all the stakeholders about violation of human rights by corruption and to present policy recommendations that can be helpful in curbing corruption. Furthermore, specific guidance should be given to all the stakeholders; for example, this systematic review shows how and why public spending on health and education can be diverted through corruption and how a state can reduce the level of corruption. Policy recommendations such as social audit may strengthen transparency and accountability mechanisms in developing countries.

Importance for Central European Journal of Public Policy

Central and Eastern European countries suffer from corruption, as Placek et al $(2019,2021)$, for instance, argue that postcommunist countries such as Czechoslovakia and Bulgaria exhibit high level of corruption. These countries were a 'scarcity' society ruled by the citizens' unsatisfied demand for goods and services that compelled citizens to pay bribes to public officials for gaining public goods/services. Such a situation further created a culture of 'demand and supply of corrupt practices' within the entire system of governance. This study offers different perspectives for developing countries in terms of comparison if there is any similar path. Therefore, it can be significant for readers and future researchers within the arena of corruption and human rights perspective from Central and Eastern European countries.

\section{CONCLUSION}

The issue of corruption has globally taken the pace of interest, but its alarming consequences have overwhelmed the developing world. Corruption affects countries' social, economic and political dimensions. This paper focuses on the social sector; however, not covering the entire social sector is one of the main limitations of this research. It addresses the consequences of corruption on health and education, leaving room for future research on corruption with respect to its other social impacts. Also, this research does not analyse the political perspective, that is, political-will, which is substantially important to ensure the application of anti-corruption policies. Moreover, results identify the social problems exacerbated by corruption and provide policy recommendations. However, if such (social) issues are addressed and recommended anti-corruption policies are considered for implementation by the developing countries, it may help policy-makers to safeguard citizens' social human rights and reduce the level of perceived corruption in developing world.

Furthermore, this paper concludes that corruption disproportionately affects social human rights (health and education). The empirical shreds of evidence of Monica et al (2019) show that corruption affects physical health, for instance, mortality and life expectancy rate. According to the National Academies of Sciences, Engineering and Medicine (2018), \$445 billion out of \$7.35 trillion that is globally allocated to the health sector goes missing every year. Corruption is globally responsible for 140,000 deaths of children below the age of 5 . Reduced public spending, insufficient regulations and bad governance result in a low-quality health system. Good governance is significantly important to ensure the provision of sufficient healthcare system. Moreover, corruption in the education sector carries alarming consequences; thriving corruption in the education sector negatively affects societies, for instance, it results in fading trust, low educational quality, production of unqualified graduates and overlooking meritocracy. However, corruption is highly prevalent in the education system of developing countries. Educational corruption needs to be investigated due to its adverse effects in the society (Rumyantseva 2005).

As this study analyses human development (health and education) aspects of corruption consequences, it does not include the effects of corruption on justice and social care system in developing countries. Moreover, this paper reveals that implications of corruption on human rights should drive larger attention to the significance of addressing corruption issues within health and education. Methodologies such as SLR are underutilised to link corruption with human rights specifically. Therefore, I suggest to future researchers to examine the effects of corruption on justice and social care system and the role of civil society organisation in advocating human rights with respect to corruption, using meta-analysis of systematic review. 


\section{ACKNOWLEDGEMENT}

This study was supported by Charles University in Prague by the grant SVV 260596.

\section{REFERENCES}

Achim, M. V., Văidean, V. L., \& Borlea, S. N. (2020). Corruption and health outcomes within an economic and cultural framework. The European journal of health economics, 21(2), 195-207. Available

Adsera, A., Boix, C., \& Payne, M. (2003). Are you being served? Political accountability and quality of government. The Journal of Law, Economics, and Organization, 19(2), 445-490.

Ahmad, I., Rauf, M., Rashid, A., ur Rehman, S., \& Salam, M. (2013). Analysis of the problems of primary education system in Pakistan: Critical review of literature. Academic Research International, 4(2), 324.

Akçay, S. (2006). Corruption and human development. Cato J., 26, 29.

Akhter, S. H. (2004). Is globalization what it's cracked up to be? Economic freedom, corruption, and human development. Journal of World Business, 39(3), 283-295.

Ali, Z. (2020). Pakistan's National Accountability Ordinance and the facilitation of corrupt practices. Contemporary South Asia, 28(1), 86-99.

Angeles, L., \& Neanidis, K. C. (2015). The persistent effect of colonialism on corruption. Economica, 82(326), 319-349.

Anwar, T., \& Bilquees, F. (2003). Trends in Inequality in Pakistan between 1998-99 and 2001-02 [with Comments]. The Pakistan Development Review, 42(4), 809-821.

Asian Development Bank, country briefing paper-women in Pakistan, July 2000.

Assembly, U. G. (1948). Universal declaration of human rights. UN General Assembly, 302(2), 14-25

Banque mondiale. (2014). Global monitoring report 2014/2015: Ending poverty and sharing prosperity. World Bank, 1-243.

Bardhan, P. (1997) 'Corruption and Development: A Review of Issues*, Journal of Economic Literature , 35, 3, pp. 13

Bashir, S., Khattak, H. R., Hanif, A., \& Chohan, S. N. (2011). Whistleblowing in public sector organizations: Evidence from Pakistan. The American Review of Public Administration, 41(3), 285-296.

Bayley, D. H. (1966). The effects of corruption in a developing nation. Western political quarterly, 19(4), 719-732.

Buscaglia, E. (2003, December). Controlling organized crime and corruption in the public sector. In Forum on crime and society (Vol. 3, No. 1/2), 1-32.
Caillier, J. (2010). Citizen trust, political corruption, and voting behavior: Connecting the dots. Politics \& Policy, 38(5), 1015-1035

Capoccia, G. (2016). When do institutions "bite"? Historical institutionalism and the politics of institutional change. Comparative Political Studies, 49(8), 1095-1127.

Chauchard, S., Klašnja, M., \& Harish, S. P. (2019). Getting Rich Too Fast? Voters' Reactions to Politicians' Wealth Accumulation. The Journal of Politics, 81(4), 1197-1209.

Chen, C., \& Neshkova, M. I. (2020). The effect of fiscal transparency on corruption: A panel cross-country analysis. Public Administration, 98(1), 226-243.

Chêne, M. (2008). Overview of corruption in Pakistan. Transparency International, 1-13.

Cheng, C. Y., \& Urpelainen, J. (2019). Criminal Politicians and Socioeconomic

Estache, A., Wren-Lewis, L., Rose-Ackerman, S., \& Soreide, T. (2011). Anticorruption policy in theories of sector regulation. Chapter, 9, 269-299.

Development: Evidence from Rural India. Studies in Comparative International Development, 54(4), 501-527.

Choudhry, S. (2014). Pakistan: a journey of poverty-induced shame. The Shame of It. Global Perspectives on Anti-Poverty Policies, 111-132.

Conceição, P. (2019). Human Development Report 2019, Beyond income, beyond averages, beyond today: inequalities in human development in the 21st century. United Nations development Programme, 1-366.

Corruption Perception Index Report (2018). Available at https://www. transparency.org/files/content/pages/2018_CPI_ExecutiveSummary.pdf

Corruption Perception Index Report (2019). Available at https://www. transparency.org/files/content/pages/2019_CPI_Report_EN.pdf

Delavallade, C. (2006). Corruption and distribution of public spending in developing countries. Journal of economics and finance, 30(2), 222-239.

Dhaktode, N. (2016). 13 Role of social audit in curbing corruption in India. Governance in South Asia, 233.

Englebert, P. (2000). Pre-colonial institutions, post-colonial states, and economic development in tropical Africa. Political research quarterly, 53(1), 7-36. 
Farooq, A., Shahbaz, M., Arouri, M., \& Teulon, F. (2013). Does corruption impede economic growth in Pakistan?. Economic Modelling, 35, 622-633.

Finfgeld-Connett, D., \& Johnson, E. D. (2013). Literature search strategies for conducting knowledge-building and theory-generating qualitative systematic reviews. Journal of advanced nursing, 69(1), 194-204.

Garuba, H. A., Kohler, J. C., \& Huisman, A. M. (2009). Transparency in Nigeria's public pharmaceutical sector: perceptions from policy makers. Globalization and health, 5(1), 14.

Gebeye, B. A. (2012, June). Corruption and human rights: Exploring the relationships. In Human rights \& human welfare. A forum for works in progress. Working paper (No. 70), 1-44.

Gupta, S., De Mello, L., \& Sharan, R. (2001). Corruption and military spending. European journal of political economy, 17(4), 749-777.

Hallak, J., \& Poisson, M. (2005). Ethics and corruption in education: an overview. Journal of education for international development, 1(1), 1-3.

Heeks, R., \& Mathisen, H. (2012). Understanding success and failure of anti-corruption initiatives. Crime, Law and Social Change, 58(5), 533-549.

Heyneman, P. (2003). Education and misconduct. In James Guthrie (ed.), Encyclopedia of Education. New York: Maxmillan Publishers, Vol. 5, pp. $1659-68$.

Hoffmann, L. K., \& Patel, R. N. (2017). Collective action on corruption in Nigeria: A social norms approach to connecting society and institutions (pp. 1-53). London: Chatham House.

Hsiao, A., Vogt, V., \& Quentin, W. (2019). Effect of corruption on perceived difficulties in healthcare access in sub-Saharan Africa. PloS one, $14(8), 1-12$.

Hu, B., \& Mendoza, R. U. (2013). Public health spending, governance and child health outcomes: revisiting the links. Journal of Human Development and Capabilities, 14(2), 285-311.

International Bill of Human Rights, available at https://www.ohchr.org/ documents/publications/compilation1.1en.pdf

International Covenant on Civil and Political Rights, available at https:// www.ohchr.org/Documents/Professionallnterest/ccpr.pdf

International Covenant on Economic, Social and Cultural Rights, available at https://www.ohchr.org/Documents/Professionallnterest/ cescr.pdf

Ionescu, L. (2013). The role of technology in combating corruption. Economics, Management, and Financial Markets, 8(3), 101106.

Jain, A. K. (Ed.). (2001). The political economy of corruption (Vol. 2). Routledge.
Javaid, U. (2010). Corruption and its deep impact on good governance in Pakistan. Pakistan Economic and Social Review, 123-134.

Johnston, M. (1998). Fighting systemic corruption: Social foundations for institutional reform. The European Journal of Development Research, 10(1), 85-104.

Justesen, M. K., \& Bjørnskov, C. (2014). Exploiting the poor: Bureaucratic corruption and poverty in Africa. World Development, 58, 106-115.

Khan, F. (2007). Corruption and the Decline of the State in Pakistan. Asian Journal of Political Science, 15(2), 219-247.

Khan, F. (2016). Combating corruption in Pakistan. Asian Education and Development Studies, 1-16.

Khan, M. T., Khan, N. A., Ahmed, S., \& Mehmood, K. (2012). Corruption: causes and effects in Pakistan's case (A review research). International Journal of Business and Behavioral Sciences, 2(6), 79-91.

Kofele-Kale, N. (2000). The right to a corruption-free society as an individual and collective human right: elevating official corruption to a crime under international law. The International Lawyer, 149-178.

Lambsdorff, J. G. (2007). The institutional economics of corruption and reform: Theory, evidence and policy. Cambridge university press, 236-254

Lewis, M. (2006). Governance and corruption in public health care systems. Center for Global Development working paper, (78), 1-57.

Machoski, E., \& de Araujo, J. M. (2020). Corruption in public health and its effects on the economic growth of Brazilian municipalities. The European Journal of Health Economics, 1-19.

Macrae, J. (1982). Underdevelopment and the economics of corruption: A game theory approach. World Development, 10(8), 677-687.

Mahoney, J. (2000). Path dependence in historical sociology. Theory and society, 29(4), 507-548.

Maureen, L. (2006). Governance and corruption in public health care systems. Center for Global Development working paper, 78, 1-57.

Mauro, M. P. (1996). The Effects of Corruptionon Growth, Investment, and Government Expenditure (No. 96-98). International Monetary Fund.

Mauro, P. (1998). Corruption and the composition of government expenditure. Journal of Public economics, 69(2), 263-279.

Miankhail, S. B. (2009). Causes and consequences of poverty in Pakistan. Journal of Finance and Economics, 2, 2-44.

Miletzki, J., \& Broten, N. (2017). An Analysis of Amartya Sen's: Development as Freedom. Macat Library, 1-6

Moisé, G. M. (2020). Corruption in the oil sector: A systematic review and critique of the literature. The Extractive Industries and Society, 7(1), 217-236. 
Molina, E., Carella, L., Pacheco, A., Cruces, G., \& Gasparini, L. (2017). Community monitoring interventions to curb corruption and increase access and quality in service delivery: a systematic review. Journal of Development Effectiveness, 9(4), 462-499.

Morgan, A. (1998). Corruption: causes, consequences, and policy implications. The Asia Foundation, San Francisco, 1-57.

Murphy, K. M., Sleifer, A. \& Vishny, R. W. (1993) 'Why is Rent-Seeking So Costly to Growth?', American Economic Review , 83, 2, pp.

National Academies of Sciences, Engineering, and Medicine. (2018). Crossing the global quality chasm: Improving health care worldwide. National Academies Press, 1-399.

Ndaguba, E., ljeoma, E. O. C., Nebo, G. I., Chungag, A. C., \& Ndaguba, J. D. (2018). Assessing the effect of inadequate service provision on the quality of life of the poor: A focus on justice and education in Nigeria. Cogent Social Sciences, 4(1), 1526437.

Nowak, R. (2000). Corruption and transition economies. Foreign Policy, 155 .

Onwujekwe, O., Agwu, P., Orjiakor, C., McKee, M., Hutchinson, E., Mbachu, C., ... \& Balabanova, D. (2019). Corruption in Anglophone West Africa health systems: a systematic review of its different variants and the factors that sustain them. Health policy and planning, 34(7), 529-543.

Osaghae, E. E. (2006). Colonialism and civil society in Africa: The perspective of Ekeh's two publics. Voluntas: International Journal of Voluntary and Nonprofit Organizations, 17(3), 233-245.

Osipian, A. L. (2007). Corruption in higher education: Conceptual approaches and measurement techniques. Research in Comparative and International Education, 2(4), 313-332.

Pahlevan-Sharif, S., Mura, P., \& Wijesinghe, S. N. (2019). A systematic review of systematic reviews in tourism. Journal of Hospitality and Tourism Management, 39, 158-165.

Paredes-Solís, S., Andersson, N., Ledogar, R. J., \& Cockcroft, A. (2011). Use of social audits to examine unofficial payments in government health services: experience in South Asia, Africa, and Europe. BMC Health Services Research, $11\left(\mathrm{~S}_{2}\right), \mathrm{S}_{12}$.

Peters, A. (2015). Corruption and human rights. Basel Institute on Governance Working Paper, (20), 1-34.

Plaček, M., Půček, M., \& Ochrana, F. (2019). Identifying corruption risk: A comparison of Bulgaria and the Czech Republic. Journal of Comparative Policy Analysis: Research and Practice, 21(4), 366-384.

Plaček, M., Půček, M., \& Ochrana, F. (2019). Identifying corruption risk: A comparison of Bulgaria and the Czech Republic. Journal of Comparative Policy Analysis: Research and Practice, 21(4), 366-384.
Plaček, M., Valentinov, V., Ochrana, F., Vaceková, G., Langr, I., \& Pưček, M. (2021). The evolving perceptions of corruption in Czechoslovakia and the Czech Republic. Governance, 1-9.

Please, S., \& Amoako, K. Y. (1984). The World Bank's report on accelerated development in Sub-Saharan Africa: a critique of some of the criticism. African Studies Review, 27(4), 47-58.

Qizilbash, M. (2001). Corruption and human development: A conceptual discussion. Oxford Development Studies, 29(3), 265-278.

Quah, J. S. (2008). Curbing corruption in India: An impossible dream?. Asian Journal of Political Science, 16(3), 240-259.

Robb, G. (1991). White-collar crime in modern England: Financial fraud and business morality, 1845-1929.

Rose, R., \& Peiffer, C. (2018). Bad governance and corruption. Springer.

Rose-Ackerman, S. (1999). Political corruption and democracy. Conn. J. Int'l L., 14, 363.

Rumyantseva, N. L. (2005). Taxonomy of corruption in higher education. Peabody Journal of Education, 80(1), 81-92.

Saeed, K., Jan, S. A., \& Ahmad, S. M. (2018). Corruption and Governance: Evidence from Post-9/11 Conflict Affected Pakistan. FWU Journal of Social Sciences, 12(1), 1-9.

Schimmel, B., Pech, B., \& Wiskow, M. (2004). Corruption and Gender: Approaches and Recommendations for TA: Focal Theme: Corruption and Trafficking in Women. Deutsche Gesellschaft für Technische Zusammenarbeit (GTZ).

Schwab, K. (2019, December). The global competitiveness report 2019. In World Economic Forum (pp. 9-14).

Sekalala, S., Masud, H., \& Bosco, R. T. (2020). Human rights mechanisms for anti-corruption, transparency and accountability: enabling the right to health. Global health action, 13(sup1), 1699343.

Seldadyo, H., Elhorst, J. P., \& De Haan, J. (2010). Geography and governance: Does space matter?. Papers in Regional Science, 89(3), 625-640.

Sen, A. (2001). Development as freedom. Oxford Paperbacks.

Sewell, W. H. (1996). Three temporalities: Toward an eventful sociology. The historic turn in the human sciences, 98, 245-280.

Shabbir, G., \& Anwar, M. (2007). Determinants of corruption in developing countries. The Pakistan Development Review, 751-764.

Shleifer, A., \& Vishny, R. W. (1993). Corruption. The quarterly journal of economics, 108(3), 599-617.

Tanzi, V. (1998). Corruption around the world: Causes, consequences, scope, and cures. Staff Papers, 45(4), 559-594. 
Tiongson, M. E., Davoodi, M. H. R., \& Gupta, M. S. (2000). Corruption and the provision of health care and education services (No. 0-116). International Monetary Fund.

Trace International (2017). Trace bribery risk index. Available at https:// www.traceinternational.org/trace-matrix?year $=2017$

Tran, N. A. (2008). Corruption and human development. Development and Policies Research Center (DEPOCEN), Vietnam, Working Paper, (7).

Transparency International Pakistan Report (2010). Available at http:// www.transparency.org.pk/pr/cpi2010.pdf

Ugur, M., \& Dasgupta, N. (2011). Evidence on the economic growth impacts of corruption in low-income countries and beyond: a systematic review. EPPI-Centre Social Science Research Unit, Institute of Education, University of London, 1-134.

Ugur, M., \& Dasgupta, N. (2011). Evidence on the economic growth impacts of corruption in low-income countries and beyond: a systematic review. EPPI-Centre Social Science Research Unit, Institute of Education, University of London, 1-140.

Universal Declaration of Human Rights, available at https://www.ohchr. org/en/udhr/documents/udhr_translations/eng.pdf

Uzma Afzal, Anam Yusuf (2013). The State of Health in Pakistan, September, The Labore Journal of Economics, 1-15.

Verkaaik, O. (2001). The captive state: Corruption, intelligence agencies, and ethnicity in Pakistan. States of imagination: Ethnographic explorations of the postcolonial state, 345-64.

WHO (2009). Diarrhoea: why children are still dying and what can be done. Geneva: UNICEF/WHO, 1-64.

Xezonakis, G., Kosmidis, S., \& Dahlberg, S. (2016). Can electors combat corruption? Institutional arrangements and citizen behaviour. European Journal of Political Research, 55(1), 160-176. 